\title{
ІНФОРМАЦЙНІ ТЕХНОЛОГІЇ НА ЗАСАДАХ ПРИНЦИПУ ІНДИВІДУАЛІЗАЦІЇ САМОСТІЙНОЇ НАВЧАЛЬНОЇ ДІЯЛЬНОСТІ СТУДЕНТІВ ФІЛОЛОГІЧНИХ СПЕЦІАЛЬНОСТЕЙ
}

Малоіван М. В. Інформаційні технології на засадах принципу індивідуалізації самостійної навчальної діяльності студентів філологічних спеціальностей.

У статті розглядається індивідуалізація самостійної навчальної діяльності засобами інформаційних технологій. Стаття розкриває теоретичне осмислення необхідності індивідуалізації самостійної навчальної діяльності студентів філологічних спеціальностей засобами інформаційних технологій, які максимально активізують роботу студентів та надають широкі можливості, впливаючи на якість освіти.

Ключові слова: індивідуалізація, самостійна навчальна діяльність, індивідуалізація самостійної навчальної діяльності, принципи індивідуалізації, інформаційні технології.

Малоиван М. В. Информационные технологии на принципах индивидуализации самостоятельной учебной деятельности студентов филологических специальностей.

В статье рассматриваются информационные технологии как способ активизации индивидуализации самостоятельной учебной деятельности. Статья раскрывает теоретические аспекты необходимости индивидуализации самостоятельной учебной деятельности студентов средствами информационных технологий, которые максимально активизируют работу студентов и представляют им широкие возможности, влияя на качество образования.

Ключевые слова: индивидуализация, самостоятельная учебная деятельность, индивидуализация самостоятельной учебной деятельности, принципы индивидуализации, информационные технологи.

Maloivan M. V. Information technologies based on the principles of individualization of self-education.

The issue of individualization of self-education via information technologies is under consideration in this article. The article deals with the theoretical basement of the necessity of the individualization of the students' self-study with the help of information technologies which activate their work during the educational process favouring the quality of education.

Key words: individualization, self-studying, individualization of self-studying, principles of individualization, information technology.

Інформаційні процеси в освіті, інтеграція освіти до єдиного світового простору, особистісно зорієнтовне навчання сприяють необхідності внесення змін до сучасної парадигми навчання у вищій школі.

Згідно з сучасними тенденціями навчання пріоритетною метою $є$ підготовка компетентного спеціаліста, який володіє здатністю розв'язувати поставлені завдання в різних умовах, отримувати нові знання, приймати рішення, нестандартно мислити й активно діяти. Одним із резервів реалізації ефективності підготовки студентів $є$ підвищення ролі самостійної навчальної діяльності, яка грунтується на основі врахування індивідуальних особливостей кожного студента. Інформаційні технології становлять собою один із 
дидактичних засобів активізації самостійної навчальної діяльності студентів філологічних спеціальностей.

Значимі аспекти формування самостійної навчальної діяльності були теоретично обгрунтовані в працях М. Махмутова, П. Підкасистого та інших, однак, в рамках парадигми традиційної освіти, яка розкриває тільки організаційну сторону самостійної навчальної діяльності. Сучасна особистісно зорієнтована парадигма вимагає внесення змін та використання інших підходів до організації самостійної навчальної діяльності, ураховуючи індивідуальні особливості та використовуючи інформаційні технології.

Різні аспекти використання засобів інформаційних технологій у ВНЗ висвітлюються в працях ряду спеціалістів (О. Безпалов, І. Дровникова, А. Сіцінський, С. Федорова); завдання інформатизації та індивідуалізації самостійної навчальної діяльноості виріщували в своїх роботах І. Бех, В. Володько, П. Гусак, М. Кривко, Л. Мартіросян, В. Сєрикова, Л. Смалько, О. Пєхота, І. Унт, І. Якиманська, Р. Завізєна, Д. Таушан, С. Яшанов, а питанням самостійної організації навчальної діяльності із застосуванням комп’ютерів займалися Б. Гершунський, В. Глушков, О. Єршов, В. Коржуков та інші.

Праці зарубіжних науковців $\quad$ Р. Гронмунда, Дж. Дьюї, А. Чікеринга та інших присвячені формам і методам індивідуалізації навчання й самостійної навчальної діяльності зокрема.

Mета статmі - теоретично обгрунтуванні індивідуалізації самостійної навчальної діяльності студентів філологічних спеціальностей засобами інформаційних технологій.

Важливим аспектом парадигми сучасної освіти $\epsilon$ індивідуалізація самостійної навчальної діяльності, яка сприяє формуванню позитивного, зацікавленого ставлення студентів до самостійної та відповідальної реалізації цілей підготовки, здатності обгрунтовано та самостійно робити вибір та приймати рішення.

Студент, який не підготовлений до самостійного здобуття нових знань, не зможе розвинути в собі ці якості у процесі професійної діяльності. Саме тому ВНЗ покликані забезпечити не тільки високий рівень професійних знань і вмінь студентів, але і сформувати творчу особистість фахівця, здатного до самовдосконалення й самоосвіти. Науково правильно організована й систематично здійснювана самостійна навчальна робота $\epsilon$ необхідною умовою успішного навчання, одним із визначальних чинників, що впливає на професійне становлення особистості.

Сучасна концепція вищої освіти пов'язує хід та результати навчання 3 рівнем організації самостійної роботи студентів на різних його етапах. На думку науковців, система вищої освіти покликана не лише давати студентам певну систему знань, формувати в них професійні вміння та навички, розвивати творче мислення, але й озброювати методикою самостійного пошуку і здобуття інформації, необхідної для подальшої професійної діяльності.

Дослідивши сутність поняття самостійної навчальної діяльності, викладені в працях багатьох авторів (А. Алексюка, Г. Гнитецької, . Єсипова, В. Козакова, Р. Нізамова), вивчивши особливості організації даної діяльності, ми прийшли до висновку, що воно $є$ багатоаспектним та не має чіткого та єдиного визначення в педагогічній літературі. Так, С. Архангельський трактує це поняття як самостійний пошук інформації, отримання знань та їх використання для розв’язання навчальних, наукових та професійних завдань. У трактуванні інших авторів (Т. Квасюк, І. Деркач та інші) самостійна навчальна діяльність визначається як різні види індивідуальної, групової пізнавальної діяльності студентів на заняттях без безпосереднього керівництва, але під наглядом викладача, система організації 
педагогічних умов, що забезпечують керівництво навчальною діяльністю, яка має місце за відсутності викладача; засіб тренування у студентів психологічної установки на систематичне поповнення своїх знань та вмінь орієнтуватися в потоці інформації тощо [1, с. 115].

Вивчивши специфіку досліджуваного явища через вивчення праць педагогівтеоретиків і проаналізувавши особливості організації практичної діяльності з теми, ми виявили, що самостійна навчальна діяльність становить діяльність, яка планується, реалізується в аудиторний і позааудиторний час 3 метою усвідомленого опанування матеріалом та за методичним керівництвом викладача.

Самостійна навчальна діяльність представляє собою дидактичне явище, що розкриває механізм трансформації викладання із зовнішньої площини навчального процесу у внутрішню (особистісну) площину.

Складність організації самостійної навчальної діяльності полягає в розмаїтті та неоднозначності її сутності. Відповідно до Положення про організацію навчального процесу у вищих навчальних закладах [7] «самостійна робота студента $\epsilon$ основним засобом оволодіння навчальним матеріалом у час, вільний від обов’язкових навчальних занять».

Підготовка студентів філологічних спеціальностей до самостійної навчальної роботи й керівництво нею, поділяється на три блоки:

1) мотиваційний;

2) технологічний;

3) організаційний.

1. Мотиваційний блок. Цей блок створюється з метою цілеспрямованого акцентування викладачами значущості самостійної роботи для опанування всієї системи знань з певної дисципліни.

2. Технологічний блок. В основі його лежить завдання навчити студентів вміло користуватися матеріально-технічною базою.

3. Організаційний блок. Сама суть самостійної роботи передбачає здатність студента до самоорганізації, але як свідчить практика педагогічної праці, цей процес проходить значно успішніше, якщо викладач в загальних рисах визначить студентам, що повинно стати результатом самостійної роботи і яким чином його досягти.

Основними функціями самостійної навчальної діяльності студентів $є$ [3, с. 36]:

1. Освітня (навчальна), суть якої полягає в тому, що в процесі перевірки поглиблюються та удосконалюються знання, вміння та навички, підвищується рівень освіченості, удосконалюються культура розумової праці, стимулюється самостійність студентів, розвиваються їх пізнавальні інтереси. 2. Розвивальна- в процесі навчання у студентів розвивається логічне мислення, зокрема вміння аналізу і синтезу, порівняння й узагальнення, абстрагування і конкретизації, класифікації та систематизації, мислення, мовлення, пам’ять, уява, увага. Однак слід зазначити, що ця функція може бути реалізованою лише за умов, якщо питання, які пропонують студентам, будуть вимагати від них пояснень, доказів. 3. Діагностувальна, у процесі якої виявляють успіхи та недоліки в знаннях, уміннях і навичках студентів, встановлюють причини і шляхи їх усунення, визначають заходи спрямовані на покращення успішності. 4. Стимулювальна - схвалення успіхів студентів сприяє розвитку в ньому спонукальних мотивів до самостійної роботи. 5. Оцінювальна об’єктивна оцінка знань, а також ступінь володіння методами пізнання, прийомами емпіричного та теоретичного мислення. Невід’ємною частиною цієї функції є самоконтроль. 6. Управлінська, на основі цієї функції визначається стан успішності студентів, що надає 
змогу запобігти неуспішності або подолати їі. В цьому випадку викладач (тьютор) коригує і свою власну діяльність.

Проблема організації самостійної навчальної діяльності студентів та іï індивідуалізація є однією з актуальних у сучасній педагогіці. На сучасному етапі склалася ситуація, коли закоренілі засоби та форми проектування та здійснення самостійної навчальної діяльності вимагають осмислення, корекції та нових педагогічних рішень. Це зумовлено, насамперед, розширенням поля самостійної навчальної діяльності студентів в умовах залучення до процесу пізнання інформаційних технологій, що формують навички самоорганізації та самонавчання.

Отже, саме використання інформаційних технологій сприяє максимальній активізації та індивідуалізації роботи студентів, з одного боку, спрямовуючи її, з іншого, - надаючи їм змогу самостійно керувати своєю пізнавальною діяльністю. Інформаційні технології надають широкі можливості студентам, впливаючи на якість засвоєння матеріалу та на якість освіти в цілому.

Навчання за допомогою інформаційних технологій використовується для його індивідуалізації, а тому важливо застосовувати комп’ютерні навчальні програми під час самостійної навчальної діяльності студентів філологічних спеціальностей.

На сучасному етапі освіти інформаційні технології широко впроваджуються на всіх рівнях освіти. Як засіб навчання комп’ютер використовується для розвитку вмінь та навичок алгоритмізації рішення завдань i формування на цій основі логічного системного мислення [2, с. 39]. Якщо навчальні програми складені з урахуванням розвитку розумових здібностей людини (спостережливості, асоціативності, порівняння, аналогії, виділення головного, узагальнення, уяви тощо), то результатом використання подібних програм $€$ прищеплення загальнонаукових (насамперед, гностичних та організаційних) умінь та навичок [3]. Система навчання з використанням інформаційних технологій здатна збагатити процес навчання студентів, роблячи його більш активним та навіть інтерактивним. Така система дозволить вищим навчальним закладам більш ефективно виконувати свою роль та здійснювати освітні функції, забезпечувати більш широкий доступ до інформації [4, с. 43]. Використання у процесі навчання інформаційних технологій та повторення матеріалу засобами цих програм дозволяють вносити у матеріал основні уявлення про предмет вивчення, а в інформаційно-пошуковому програмному засобі представити матеріал у повному обсязі. Як результат, значно зменшується час пояснення матеріалу, зростає інтерес до навчання, забезпечується індивідуалізація навчання, розвиваються здібності самостійної роботи й дослідницької діяльності студентів [5].

Отже, інформаційні засоби навчання у вищій освіті дозволяють у повному обсязі реалізувати принцип самостійного отримання знать та формування умінь та навичок. Вони дозволяють кожному студенту реалізовувати індивідуальну стратегію викладання, обирати час та тривалість занять, реалізовувати контроль за динамікою своїх досягнень.

Проаналізувавши теоретичні дослідження, можливо виокремити такі переваги використання інформаційних технологій при навчанні:

- додаткові можливості інтенсифікації й індивідуалізації навчального процесу;

- різні види наочності;

- можливість передати частину функцій викладача машині, за рахунок автоматиації шаблонних дій;

- доступ до інформаційно-довідкових ресурсів дає студентам необмежені 
навчальні матеріали;

- інтерактивність, тобто студенти отримують можливість зворотного зв'язку, який інформує їх щодо правильності дій. Такий зворотній зв’язок може бути як оперативним, так і відстроченим у вигляді оцінки;

- підвищення мотивації за рахунок створення умов, які сприяють підвищенню зацікавленості предметом;

- можливість автоматизованого контролю, урахування результатів навчального процесу та більш об’єктивного оцінювання знань та умінь [4; 5; 6].

Використання інформаційних технологій в організації самостійної навчальної діяльності студентів дозволяє не тільки інтенсифікувати їх роботу, а й закладає основи їх подальшої постійної самоосвіти, отже, педагогічне інформаційно-освітнє середовище, яке створюється за допомогою інтеграції сукупності програмно-апаратних та традиційних форм навчання, і визначає самостійну навчальну діяльність студента як більш незалежну і творчу.

\section{Література}

1. Гершунский Б. С. Компьютеризация в сфере образования: Проблемы и перспективы : [учеб. пос.] / Б. С. Гершунский. - Москва : Педагогика, 1987. - 264 с. 2. Котляр Л. М. Организация самостоятельной работы по математике с помощью современных информационных технологий / Л. М. Котляр, Ж. И. Зайцева, Л. Б. Фоменко // Фундаментальные исследования. - 2004. - № $5-\quad$ С. 15-18. $\quad$ 3. Лобачев С. Л. Информационно-образовательная среда открытого образования / С. Л. Лобачев, А. Поляков // Народное образование. - 2000. - № 8. - С. 43-47. 4. Полат Е. С. Новые педагогические и информационные технологии в системе образования: [учеб. пособ.]/ Е. С. Полат. - Москва : Издательский центр «Академия», 2005 - 272 с. 5. Положення про організацію навчального процесу у вищих навчальних закладах: Затверджене Наказом МОН України від 2.06.93 № 161. 6. Роберт И. В. Информационные и коммуникационные технологии в образовании : [учеб. пособ.] / И. В. Роберт. - Москва : Дрофа, 2008. - 312 с. 7. Селевко Г. К. Педагогические технологии на основе информационно-коммуникационных средств: [учеб. пособ.] / Г. К. Селевко. - Москва : НИИ школьных технологий, 2004. - 224 с.

УДК 378.147:510.6:004

Марія Медведєва

\section{ВИКОРИСТАННЯ ОСВІТНЬОГО РЕСУРСУ У ВИГЛЯДІ САЙТУ «ДИСКРЕТНА МАТЕМАТИКА» ЗА УМОВ ОСОБИСТІСНО ЗОРІЄНТОВАНОГО НАВЧАННЯ}

Медведєва М. О. Використання освітнього ресурсу у вигляді сайту «Дискретна математика» за умов особистісно зорієнтованого навчання.

У статті обгрунтовано актуальність та доцільність використання освітнього Інтернетресурсу у вигляді сайту «Дискретна математика», що використовується за особистісно зорієнтованого навчання дискретної математики з використанням інформаційних технологій у вищих навчальних закладах. Описано технології, що використовувалися під час створення пропонованого сайту.

Ключові слова: дискретна математика, інформаційні технології, вищий навчальний заклад, особистісно зорієнтоване навчання, навчально-пізнавальна діяльність.

Медведева М. А. Использование образовательного ресурса в виде сайта «Дискретная 